\title{
Reconsidering the Freedom Charter, the black theology of liberation and the African proverb about the locust's head in the context of poverty in South Africa
}

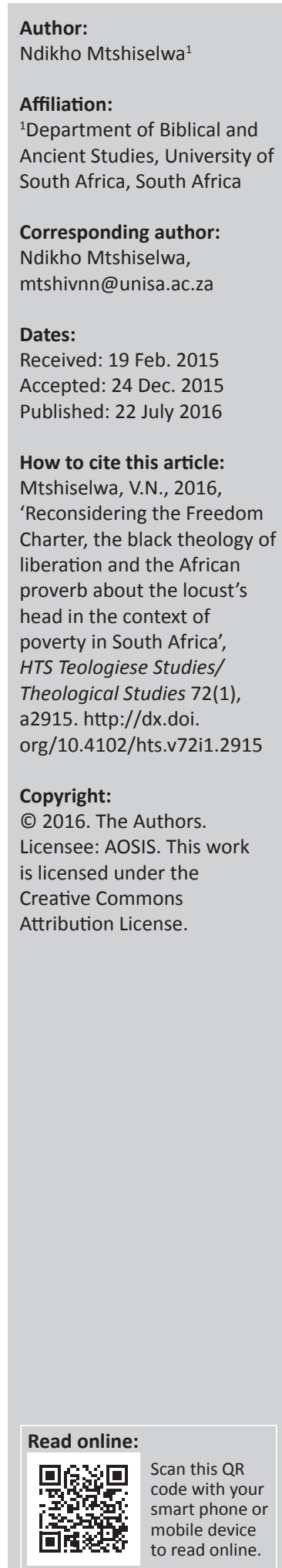

While South Africa attained liberation from the apartheid rule in 1994, the legacy of colonialism and apartheid - in the form of poverty and economic inequality - continues to haunt black South Africans. The aim of this article is to make a case for the equitable sharing of South Africa's mineral wealth amongst all its citizens with the view to alleviate poverty. Firstly, this article provides a reflection on the Freedom Charter and suggests that the values of the Charter, for instance, the sharing of resources and wealth, are relevant in South Africa today. Secondly, it is argued in the present article that the preferential option for the poor which is upheld in the black theology of liberation is equally relevant in post-apartheid South Africa where many black South Africans remain poor. Thirdly, this article argues that the African proverb, Bana ba motho ba ngwathelana hlogo ya tšie [The siblings share the head of a locust], also echoes the idea of equitable sharing of resources with a view to alleviate poverty. Lastly, the author submits that the idea of equitable sharing of resources and wealth that is echoed in the Freedom Charter, the black theology of liberation and the African wise saying support the equitable redistribution of the mineral wealth to the benefit of all South Africans.

\section{Introduction}

In 2015, South Africans celebrated the 50th anniversary of the Freedom Charter (hereafter referred to as the Charter) which was adopted at the Congress of the People on 26 June 1955 (South African Congress Alliance 1955). Masenya [ngwan'a Mphahlele] (2004:69) uses the term African-South Africans to refer to people who were initially labelled, 'native' and since 1921 labelled 'Bantu' and 'black', who are of African descent whose home language is Xhosa, Ndebele, Sotho, Tswana, Zulu, Venda, and so forth. However, because the interlocutor of black theology of liberation is a black person, or because blackness contours are not narrowed to the preceding group of persons, the term 'black South Africans' will be used here to refer to persons of African descent. Although the designation 'black' includes Indian and coloured persons in South Africa, it will however be employed in this article to refer specifically to persons of African descent whose home language is Xhosa, Ndebele, Sotho, Tswana, Zulu and Venda, among other indigenous languages in the country. The use of the phrase 'black South Africans' is also motivated by the fact that it is germane to the present discourse of the black theology of liberation, the Charter and the African proverb under consideration.

It is noteworthy that the Charter has made a significant contribution to the shaping of South Africa's democracy. This paper does not intend to illustrate how the demand, 'the people shall govern', has been achieved in that the present government is led by the previously disadvantaged persons, namely, black South Africans. It also does not aim to offer a comprehensive analysis of how the doors of learning have been opened to all South Africans as the Charter demanded. In addition, this paper does not focus on the fact that the South African government has been inspired by the stipulations of the Charter to provide poor black South Africans with houses. Rather, this study attempts to provide in part a reflection on the demand for the equitable sharing of the country's wealth which is expressed in the well-known clause:

The national wealth of our country, the heritage of all South Africans, shall be restored to the people; the mineral wealth beneath the soil, the Banks and monopoly industry shall be transferred to the ownership of the people as a whole; all other industry and trade shall be controlled to assist the wellbeing of the people; all people shall have equal rights to trade where they choose, to manufacture and to enter all trades, crafts and profession. (Davies 1986:85; South African Congress Alliance 1955)

That this clause sought to address the issues of poverty and economic inequality experienced by many black South Africans, is indisputable. It is generally accepted that poverty and economic 
inequality in post-apartheid South Africa have been inherited from colonialism and apartheid (Hart 2009:21; Lehohla 2008:3; Odhiambo 2009:321; Stats SA 2012a:4; Terreblanche 2005:1). The connection between the persistent issue of poverty and the system of colonialism and apartheid in the history of South Africa warrants a reflection on the Charter, particularly with regard to the demand: 'the people shall share in the country's wealth'.

Furthermore, on the issue of poverty and land in the history of South Africa, worthy of note is the well-known anecdote:

When the white man came to our country he had the Bible and we had the land. The white man said to us 'let us pray'. After the prayer, the white man had the land and we had the Bible. (Mofokeng 1988:34)

Not only does the above anecdote offer a theological reflection on the issue of land, it also premises the discourse on land within the context of the black theology of liberation. Interestingly, the demand: 'the people shall share in the country's wealth' bears a striking similarity to the preferential option for the poor that is upheld by the black theology of liberation, and shows the connection between the Charter and black theology, as will be explained later. Furthermore, the preferential option for the poor in the black theology of liberation which calls for the alleviation of poverty and redress of economic inequality and the demand: 'the people shall share in the country's wealth' resonates with the tenor of equitable sharing of resources, implied in the Pedi proverb, Bana ba motho ba ngwathelana hlogo ya tšie [The siblings share the head of a locust]. Informed by the preceding African proverb, the black theology of liberation and the Charter, this article seeks to make a case for the equitable sharing of South Africa's mineral wealth amongst all its citizens. Therefore, it is argued that the sharing of mineral resources and wealth could alleviate poverty in post-apartheid South Africa. The discussion will follow the outline below:

- Cycle of poverty

- Freedom Charter

- Black theology of liberation

- African proverb about the locust's head

- Equitable sharing of mineral wealth.

\section{Persistent cycle of poverty in post-apartheid South Africa}

A case for the equitable sharing of the mineral wealth of South Africa in order to alleviate poverty warrants a discussion of poverty in the country. By definition, poverty is the inability to attain a minimal standard of living which is measured in terms of basic consumption needs (Odhiambo 2009:320-325; Scheepers 2010:164). Lehohla (2008:24) notes that often poverty is categorised into three levels - the upper poverty line, the lower poverty line and the food poverty line. This categorisation resonates with the situation of poverty in South Africa because the latest 2011 measurements of poverty cited by Statistics South Africa (2012b:71) reveal that the average income of the people in the upper poverty line per month is R650.00, while those of the people in the lower poverty line is R503.00 and the food poverty line is R393.00 per month. Although these measurements show different levels of poverty in South Africa, they fail to offer a view of poverty in terms of race.

On average, only $4.35 \%$ of poor people in South Africa are white compared to $61.4 \%$ of black South Africans (Stats SA 2012b:71). Not only does the data on poverty demonstrate the reality of economic inequality, it also shows that black South Africans who were disadvantaged during the colonial and apartheid regime continue to be predominantly chronically poor. As Hulme and Shepherd (2003:405) correctly perceive, chronic poverty is a state of poverty that is experienced for a period of 5 years and more (cf. McKay \& Lawson 2003:426). The view that black South Africans still experience the poverty which was inherited from the colonial and apartheid past accounts for the reality of the chronic poverty in post-apartheid South Africa (cf. Hart 2009:21; Lehohla 2008:3; Odhiambo 2009:321; Stats SA 2012a:4; Terreblanche 2005:1-2). At issue here is the probable implication that the reality of the chronic poverty in South Africa could have on the discussion about the Charter, the black theology of liberation and the African proverb locust's head. Put differently, would the values of the Charter, the black theology of liberation and the African proverb of the locust's head posit any relevance for South Africa today?

\section{Remembering the Freedom Charter in post-apartheid South Africa}

The reflection on the Charter will pay close attention to the historical context from which the Charter emerged with the view to probe the issues that the Charter sought to address. In addition, an inquiry into the merits of interpreting the Charter in the context of the nationalisation of mines will be sustained in the current article. The paper will argue that the Charter calls for the equitable sharing of the mineral wealth, and that the articulation of the influence of the neo-liberal economic globalisation on the Charter is critical.

\section{Historical context of the Freedom Charter}

Following the 1955 project of collecting the 'freedom demands' from black South Africans, the liberation movements such as the African National Congress (ANC), the South African Indian Congress, the South African Congress of Democrats and the Coloured People's Congress gathered at Kliptown to adopt the Freedom Charter. The demand that the country's natural resources be restored to the people (black South Africans) presupposes the loss of land. Thus, the observation that by 1874 black South Africans were already being dispossessed of productive land is relevant to this discussion (Maylam 1986:8; cf. Mosala 1991:42; Philpott \& Butler 2005:3; Modise \& Mtshiselwa 2013:562). At the time that the demands of the Charter 
were constructed, many black South Africans chanted the following liberation song:

iAzania Lizwe lethu [Azania is our Land]

soyithatha ngeBhazuka [We will take it with a Bazooka]

iAzania, iAzania [Azania, Azania]

Soyithatha ngeFreedom Charter [We will take it with the Freedom Charter].

When the black South African masses sang the two stanzas of this song in the heydays of apartheid, the primary issue was the massive disenfranchisement of indigenous people as well as their alienation from the productive land. Not only does the song iAzania capture the realities of apartheid South Africa, it equally presents the Charter as the solution to the disturbing reality of land dispossession because of its demand that land should be redistributed to black people. However, in contrast to the Charter, the song, iAzania inspired violence as it called for the use of the 'Bazooka' gun. Although the killing of people is unacceptable in the democratic South Africa, the persistence of economic inequality is intolerable.

Terreblanche (2012:37) argues that 'while democracy emphasised joint interest, equality and common loyalties, capitalism is based on self-seeking inequality and conflicting individual and group interests.' The view that capitalism is a system of economic self-enrichment explains the interest of the British colonialists in land with minerals in the 1800s. After diamonds were discovered in 1867 and gold in 1886, some of the British colonialists began to extract the mineral wealth of South Africa, not for the benefit of black South Africans, but for their own economic interest (Terreblanche 2012:44). Just after the discovery of diamonds in South Africa, the Native Land Act of 1913 was formulated to alienate and restrict black South Africans from acquiring productive land (Modise \& Mtshiselwa 2013:359-378). The aforementioned Act entrenched poverty among black South Africans because it perpetuated land dispossession and restricted them from accessing the productive land (Modise \& Mtshiselwa 2013:359-378). Thus, in the heydays of colonialism and apartheid the Charter was indisputably relevant.

\section{Freedom Charter and mines}

Recently, it is believed that the Charter supports the nationalisation of mines. The assumption is that the demand: '[T]he national wealth of our country, the heritage of all South Africans, shall be restored to the people' alludes to the nationalisation of mines (cf. Malinga 1990:23; Shivambu 2014:7). In my view, the argument that the nationalisation of mines is supported by the Charter is inconclusive mainly because the Charter does not explicitly mention the idea of nationalising the mines. However, the stipulation, 'the people shall share in the country's wealth', could imply that the Charter supports the equitable sharing of natural resources.

Truu (1992:274) defines nationalisation as the transfer of private ownership of assets to government ownership, against full or partial compensation (cf. Simutanyi 2010:27).
Clearly, the process of transferring the ownership of mines to the government based on the payment of compensation is not mentioned in the Charter. The clause, 'the people shall share in the country's wealth', states that the mineral wealth should be 'transferred to the ownership of the people as a whole' (South African Congress Alliance 1955:3). The interpretation of 'the people as a whole' as referring to the government would be an unfair one because not all citizens of South Africa are represented by the government. Some South Africans refrain from voting for political parties during democratic elections. In addition, the reality that not all citizens of the country would benefit from the wealth that accrues from land ownership and production in the mines renders the argument that the reference to 'the people as a whole' does not allude to the government inconclusively. Furthermore, although the statement that 'all other industry and trade shall be controlled to assist the wellbeing of the people' may refer to the control by the government, the reference is not certain (cf. South African Congress Alliance 1955:2). Thus, a reading of the nationalisation of mines into the Charter is rather speculative because the clause, 'the people shall share in the country's wealth', is silent on who should actually control trade and other industries (cf. South African Congress Alliance 1955:3).

\section{Black theology of liberation}

Striking parallels can be established between the Freedom Charter and the black theology of liberation, particularly in the context of apartheid, the issue of land dispossession and the experience of poverty by black South Africans. Firstly, both the Charter and the black theology of liberation emerged in the context of apartheid in South Africa. It is generally accepted that around 1970, the University Christian Movement (UCM) made the project of the black theology of liberation a success in South Africa (Duncan 2013:61; Hopkins 1989:31; Kretzschmar 1986:61). The black theology of liberation emerged as a critique of racism - a system of privilege that is based on race - which adversely affected black South Africans (De Gruchy \& De Gruchy 2004:144-164; Motlhabi 2007:7; Tshaka 2010:540; West 2010:161). The view that the black theology of liberation was also a critique of racism enables one to forge a link between black theology and the Charter as both sought to address the effects of racism in South Africa.

Secondly, not only does the slogan, 'Africa for Africans' show the demand for the return of the dispossessed land to black South Africans around 1970, it equally throws light on the context from which the black theology of liberation emerged (Hopkins 1989:19-20). Thus, it comes as no surprise that Mofokeng (1988:34) used the anecdote: '[A]fter the prayer, the white man had the land and we had the Bible' in his theological reflection on the issue of land. In this instance, the black theology of liberation confirms that the colonial and apartheid systems dispossessed black South Africans of their land, as Mosala (1991:40) has correctly noted. Furthermore, the black theology of liberation calls for land redistribution and socio-economic justice (cf. Maluleke 1999:63; Mosala 
1997:57-58; Philpott \& Butler 2005:18). Therefore, black theologians such as Mofokeng and Maluleke, amongst others would be sympathetic to the demand that 'the mineral wealth beneath the soil, the Banks and monopoly industry shall be transferred to the ownership of the people as a whole' in the Charter (South African Congress Alliance 1955:2).

Thirdly, the idea of the preferential option for the poor that is implied in the black theology of liberation (cf. Hopkins 2002:54) resonates with the concern for the poor highlighted in the Charter. The preferential option for the poor calls for solidarity with the oppressed people on the margins of society (Cone 1989:151-152, 1992:21, 53; Tshaka 2014:1, 2). Inspired by some Old Testament texts, namely, Proverbs 31:8-9 (which calls for and defends the rights of the poor) and Exodus 3 (which is about the liberation of the oppressed Jews), the black theology of liberation is concerned about the interests of the poor. In this case, the black theology of liberation is set to address the issue of poverty. Clearly, advancing the interests of the poor underpins the rationale behind the call for land redistribution and socio-economic justice which is upheld by the black theology of liberation (cf. Maluleke 1999:63; Mosala 1997:57-58; Philpott \& Butler 2005:18). Poor black South Africans would relate easily to the black theology of liberation because it echoes the demand for the equitable sharing of wealth.

\section{Mind the African proverb about the locust's head}

The assumption here is that the use of African proverbs can illuminate the argument in favour of the equitable redistribution of the mineral wealth in the context of poverty in South Africa. In her critique of the South African context and the reading of the Hebrew Bible, Masenya [ngwan'a Mphahlele] (2001a:186-199, 2001b:145-157) employs some Sotho proverbs to express her view (cf. Sugirtharajah 1999:100). Specifically, the Pedi proverb, Bana ba motho ba ngwathelana hlogo ya tšie, means, 'the siblings share the head of a locust'. The presupposition in this African wise saying is that the proverb emerged from the context of poverty. The noun tšie, [a locust], which is singular, refers to a single locust. Thus, an element of poverty is noticeable in the proverb. As Biko (2004:72-79) has remarked, the locust refers to one of the following: the situation of slavery, oppression or poverty. The reference to the locust insinuates that black South Africans are trapped in the cycle of poverty.

Furthermore, the argument for the equitable sharing of resources is expressed in the proverb, Bana ba motho ba ngwathelana hlogo ya tšie. The noun, bana ba motho [the siblings], is not confined to a biological relationship between people, but extends to others outside of biological relations. Thus, the interconnectedness of the community which is echoed in the proverb undergirds the idea of equitable sharing of natural resources. Put differently, unlike the idea of individualism, the ideas of interconnectedness, communalism and socialism which support the argument for equitable sharing of the mineral wealth throw light on the significance of the proverb, Bana ba motho ba ngwathelana hlogo ya tšie. The tenor of socialism and communalism underlying the economic ideology behind the equitable sharing of mineral resources would be appealing if considered closely with the given proverb. The value of equitable sharing of resources that is echoed in the proverb, Bana ba motho ba ngwathelana hlogo ya tšie resonates with both the Freedom Charter and the black theology of liberation because it also calls for the alleviation of poverty.

\section{Case for the equitable sharing of South Africa's mineral wealth}

A discussion of the influence of neo-liberal economic globalisation on the implementation of the ideals of the Charter is critical to the idea of the equitable sharing of mineral wealth that is put forward here. Demonstrating how the idea of equitable sharing of the mineral wealth in South Africa would be viable in the attempts to alleviate poverty is inseparable from the discourse of neo-liberal economic globalisation.

\section{Impact of neo-liberal economic globalisation on the Freedom Charter}

The view that neo-liberal economic globalisation is an economic system that upholds capital speculation, deregulation of markets, privatisation, unrestricted foreign investment and free movement of capital for excessive wealth creation adds an interesting dimension to the discourse on the Charter (Abramovitz \& Zelnick 2010:99; Amin 2006:2; Damon 2009:614; Smit 2009:599; Van der Westhuizen 2009:617-618). This view also explains why the Charter became an inconclusive policy document during the transition into democracy in South Africa. At the time of the transition to the post-apartheid regime, the ANC did not have a clearly formulated economic policy that would redress the legacy of economic inequality and poverty created by the systems of colonialism and apartheid, except for the Charter. That the Charter carried a commitment to the redistribution of wealth in South Africa in a bid to alleviate poverty and redress inequality through the redistribution of land, accounts for the ideology of socialism and equitable wealth sharing that undergirded it. As McKinley (2001:183-206) has observed, socialism was altered with neo-liberal economic globalisation at the time of the transition to the post-apartheid regime in South Africa. Terreblanche ascribes the change to the 'élite compromise', namely, the negotiated historical agreement between the black South African elites of the ANC and the white elites of the South African corporate sector over the nature of the economic policy and system for the post-apartheid regime (Terreblanche 2005:600, 2012:124). The essence of this compromise relates to the view that the supreme goal of the country's economic policy should be to attain a high economic growth rate, and that all other objectives should be subordinate to this (Terreblanche 2005:600). Not only did the discussion about the redistribution of natural resources become indecisive, the priority of the 
Charter, namely, the redress of socio-economic inequities in South Africa became groundless.

Regarding the issue of equal redistribution of mineral wealth amongst South Africans, Terreblanche (1991:9) argues that the privatisation of natural resources increased white ownership and white control of private business. Thus, most of the mines are owned by white South Africans and foreign companies such as Anglo American, Goldfields and AngloGold Ashanti. Furthermore, it is argued that the integration of the South African economy into the structures of global capitalism and into the neo-colonial satellite of the American led neo-liberal empire was detrimental to black South Africans (Terreblanche 1991:9). This means that the adoption of neo-liberal economic globalisation which upheld the privatisation of mines and the capitalist tendency of accumulating wealth was detrimental to the poor as it perpetuated economic inequality. It is therefore reasonable to argue that although black South Africans have attained political liberation, the legacy of socio-economic injustice has been perpetuated by the abandonment of the ideals of the Charter.

\section{Towards equitable redistribution of the mineral wealth in South Africa}

The debate on mining (see Cutifani 2013) at the 'Investing in African Mining Indaba' conference held in Cape Town on 4-7 February 2013 shows a shift from the prioritisation of revenues in the discourse on mineral wealth. Cutifani (2013) argues that the sustainability of the mining industry in Africa depends on the shift from being an extractive to becoming a development driven industry. Although the author proposes that community development should be one of the priorities of the mining companies, he does not explicitly call for the sharing of mineral wealth amongst all South Africans. Moreover, Cutifani offers no practical ways in which the poor could be developed, nor does he suggest ways in which mineral wealth could be shared equally by the rich and the poor. Unlike Cutifani, Benke (2013) holds that the mining industry needs to move from the revenue debate to the wealth sharing debate which in his view could meaningfully contribute to sustainable economic development and poverty alleviation. He proposes that (South) African governments give close attention to the requirement of the mining royalties and taxation from the mining companies with the aim of developing the infrastructure in the communities in which mining is being carried out. Although Benke makes an interesting point about the requirement of mining royalties and taxation as well as the increase of productivity, his proposal contains no viable or clear suggestion of how to alleviate poverty among black South Africans.

On the issue of the sharing of resources, worthy of note is Julius Nyerere's view which is reiterated by Ferguson (2006):

The key oppositions ... were not primarily between rival economic systems or modes of production, but between conflicting moral orientations: selfishness versus sharing, exploitation versus solidarity, [and] individual acquisitiveness versus communal mutuality. (p. 75)
However, Nyerere's approach to the issue of sharing resources which is articulated in his philosophy of Ujamaa [family hood] led to extreme poverty. The philosophy was rooted in traditional African values of equality, freedom and unity which had as its core the emphasis on 'familyhood and communalism of traditional African societies' (Ibhawoh \& Dibua 2003:62; cf. Nyerere 1967:16, 1968:27; Osabu-We 2000:171). Since the implementation of Ujamaa resulted in extreme poverty in Tanzania, Nyerere's idea of equitable sharing of resources shows that the argument for equitable sharing of mineral resources could be impracticable. However, it has been observed that the challenge with Nyerere's Ujamaa was how to extend African traditional values to the modern postcolonial setting where the economic system of capitalism is dominant (Ibhawoh \& Dibua 2003:62). Put differently, Nyerere's approach failed to navigate a viable way to implement the Ujamaa philosophy in a global context of capitalism. Instead of espousing the values of sharing, solidarity and communal mutuality, Ujamaa resulted in a selfish, exploitative and individual acquisitive approach to mineral resources. Thus, Shivji (1974:85-90) notes that Nyerere's policy of nationalisation, for instance, resulted in the use of state capital by a class of managerial elites in a manner which entirely conformed to capitalism. Instead of refuting capitalism, Ujamaa created a form of capitalism.

The argument in support of the equitable sharing of resources which is set to refute the capitalist trend of self-enrichment by the wealthy class in Africa carries weight (cf. Terreblanche 2012:37). Although the argument that the integration of the South African economy into the structures of global capitalism was detrimental to black South Africans is valid, the case for equitable sharing of wealth equally makes sense (cf. Terreblanche 1991:9). Thus, it is critical that we navigate the viability of the idea of equitable sharing of resources in an attempt to reduce poverty especially in the context of capitalism.

It seems reasonable to refrain from a complete rejection of privatisation of land based on the reality that South Africa operates within a global community which espouses neoliberal capitalism. In other words, since the business of mining operates within the global market, it may be difficult to reject completely the idea of privatisation of businesses. Hence, one would propose that at least $70 \%$ of mines in South Africa be privatised while the remaining 30\% are to be redistributed into the custody of the village chiefs. As such, the chiefs shall be accountable to the government. In addition, the mine that is redistributed into the custody of the chiefs should benefit the villages, for instance, in terms of the building of infrastructure, health facilities and schools which will in turn create employment. That is, the profit accruing from mining should be used mainly for the development of the village (which in a sense would address the issue of poverty) rather than be used to enrich black elites. The chiefs should be merely custodians and not the sole owners of the mine. The proposal to make the village chiefs the custodians of wealth would be practicable if the chiefs have a good track 
record of selfless management of communal resources. However, the issue of track record is beside the point as the chiefs could also prove their competency and care for the village, and subsequently begin to create for themselves a new track record.

With respect to the $30 \%$ of mines which could be redistributed into the custody of the village chiefs, it would not be life affirming to confiscate the mines from the current owners and leave them with no means of sustenance. That would be a reversal of socio-economic injustice. Thus, the compensation payable to the current mine owners may be $25 \%$ less than the market value of the mine. However, that percentage should be subject to the availability of the $25 \%$ of the owner's investments. If the current owners are not in a position to muster investments equivalent to the $25 \%$ of the market value of the mine, such a mine may not be expropriated without the payment of the compensation. If the owner has an amount equivalent to the market value of the mine, then, the government could expropriate the mine without the payment of compensation. In this case, the person has the capital to venture into other businesses. If a mine owner possesses more than a single mine, the government may be eligible to expropriate one of the mines without the payment of compensation. The government may pay compensation with the royalties accruing from the exports and imports of minerals as well as with the tax collected from the citizens. The government also may increase the tax required from the banks to fund the process of redistribution, that is, of the payment of compensation where necessary.

\section{Conclusion}

It has been pointed out in this article that many black South Africans continue to experience the perturbing reality of poverty and economic inequality in the post-apartheid era. That poverty and economic inequality in the South African context have been inherited from the legacy of colonialism and apartheid is irrefutable. Of significance here is the argument that the ideology behind the Freedom Charter, the black theology of liberation and the African proverb about the locust's head could be tapped to address the issue of poverty and economic inequality in South Africa. It has been argued that the preferential option for the poor upheld by the black theology of liberation, the clause, 'the people shall share in the country's wealth' in the Freedom Charter, and the Pedi proverb, Bana ba motho ba ngwathelana hlogo ya tšie [The siblings share the head of a locust] all call for the alleviation of poverty and redress of economic inequality. It is noteworthy also that the theological relationship between God and human beings seeks to overcome the selfishness of human nature that finds expression in capitalist culture. Moreover, the black theology of liberation demands the active participation of the poor miners and the village chiefs in efforts to improve the quality of life in the communities. This article has explored the call for the alleviation of poverty and redress of economic inequality, and made a case for the equitable redistribution of the mineral wealth of South Africa to benefit all citizens of the country. Since South Africa exists and operates within a global capitalist system, the case for equitable sharing of the mineral wealth is proposed. It is hoped that this article will trigger a progressive discussion of viable ways in which the idea of mineral wealth sharing could be implemented to alleviate poverty in South Africa.

\section{Acknowledgements Competing interests}

The author declares that he has no financial or personal relationships which may have inappropriately influenced him in writing this article.

\section{References}

Abramovitz, M. \& Zelnick, J., 2010, 'Double jeopardy: The impact of neoliberalism on care workers in the United States and South Africa', International Journal of Health Services 40(1), 97-117. http://dx.doi.org/10.2190/HS.40.1.f

Amin, S., 2006, 'Beyond liberal globalisation: A better or worse world?' Monthly Review, viewed 6 February 2015 from, http://monthlyreview.org/2006/12/01/ beyond-liberal-globalisation-a-better-or-worse-world

Benke, R., 2013, 'Mining's contribution to sustainable development', paper presented at the investing in African Mining Indaba, Cape Town, 5th February, 2013.

Biko, S., 2004, I write what I like, Steve Biko: A selection of his writings, Picador Africa, Johannesburg.

Cone, J.H., 1989, Black theology and black power: Twentieth anniversary edition, Harper \& Row, New York.

Cone, J.H., 1992, The blues and the spirituals, Orbis Books, Maryknoll, NY.

Cutifani, M., 2013, 'Mining's contribution to sustainable development', paper presented at the Investing in African Mining Indaba, Cape Town, 4th February, 2013.

Damon, M., 2009, 'Economic globalisation and economic justice: Covenanting for action between the Reformed Churches of South Africa and Germany', HTS Teologiese/Theological Studies 65(1), 613-616. http://dx.doi.org/10.4102/hts. v65i1.282

Davies, R., 1986, 'Nationalisation, socialisation and the Freedom Charter', paper presented at the conference on the Southern African economy after apartheid, University of York, 29th September 1986, pp. 85-106.

De Gruchy, J.W. \& De Gruchy, S., 2004, The church struggle in South Africa: 25th Anniversary Edition, SCM, London.

Duncan, G.A., 2013, 'Passive-aggressive resistance against apartheid at the Federal Theological Seminary of Southern Africa', Acta Theologica 33(1), 54-78. http:// dx.doi.org/10.4314/actat.v33i1.3

Ferguson, J., 2006, Global shadows: Africa in the neoliberal world order, Duke University, Durham.

Hart, T., 2009, Food security definitions, measurements and recent initiatives in South Africa and Southern Africa, HSRC, Pretoria.

Hopkins, D.N., 1989, Black theology USA and South Africa: Politics, culture and liberation, Orbis, New York.

Hopkins, D.N., 2002, Heart and head: Black theology, past, present and future, Palgrave, New York.

Hulme, D. \& Shepherd, A., 2003, 'Conceptualizing chronic poverty', World Development 31(3), 403-423. http://dx.doi.org/10.1016/S0305-750X(02)00222-X

Ibhawoh, B. \& Dibua, J.I., 2003, 'Deconstructing Ujamaa: The legacy of Julius Nyerere in the quest for social and economic development in Africa', African Journal of Political Science 8(1), 59-83.

Kretzschmar, L., 1986, The voice of black theology in South Africa, Ravan, Johannesburg.

Lehohla, P.J., 2008, Measuring poverty in South Africa: Methodological report on the development of the poverty lines for statistical reporting, Statistics South Africa, Pretoria.

Malinga, P., 1990, 'Nationalisation or free enterprise? The economic policy of the national democratic revolution', The African Communist 123, 20-33.

Maluleke, T.S., 1999, 'The land of the church of the land: A response to the whole issue', Bulletin for Contextual Theology in Africa 5(3), 61-64.

Masenya (ngwan'a Mphahlele), M., 2001a, 'Between unjust suffering and the "silent" God: Job and HIV/AIDS sufferers in South Africa', Missionalia 29, 186-199.

Masenya (ngwan'a Mphahlele), M., 2001b, 'A bosadi (womanhood) reading of Proverbs 31:10-31', in M.W. Dube (ed.), Other ways of reading: African women and the Bible, pp. 114-155, Society of Biblical Literature and WCC Publications, Atlanta, GA.

Masenya (ngwan'a Mphahlele), M., 2004, How worthy is the woman of worth? Rereading Proverbs 31:10-31 in African-South Africa, Peter Lang, New York.

Maylam, P., 1986, A history of the African people of South Africa: From the early iron age to the 1970s, David Philip, Cape Town. 
McKay, A. \& Lawson, D., 2003, 'Assessing the extent and nature of chronic poverty in low income countries: Issues and evidence', World Development 31(3), 425-439. http://dx.doi.org/10.1016/S0305-750X(02)00221-8

McKinley, D.T., 2001, 'Democracy, power and patronage: Debate and opposition within the African National Congress and the tripartite alliance since 1994', Democratization 8(1), 183-206. http://dx.doi.org/10.1080/714000177

Modise, L. \& Mtshiselwa, N., 2013, 'The Natives Land Act of 1913 engineered the poverty of black South Africans: A historico-ecclesiastical perspective', Studia Historiae Ecclesiasticae 39(2), 359-378.

Mofokeng, T., 1988, 'Black Christians, the Bible and liberation', Journal of Black Theology in South Africa 2(1), 34-42.

Mosala, I.J., 1991, 'Land, class and the Bible in South Africa today', Journal of Black Theology in South Africa 5(2), 40-46.

Mosala, I.J., 1997, 'Ownership or non-ownership of land forms the basis of wealth and poverty: A black theological perspective', in G. Mongezi \& L.A. Milton (eds.), An African challenge to the church in the twenty-first century, pp. 57-64, South African challenge to the church in the
African Council of Churches, Cape Town.

Motlhabi, M., 2007, African theology/black theology in South Africa: Looking back, moving on, Unisa Press, Pretoria.

Nyerere, J., 1967, Freedom and unity, Oxford University Press, London .

Nyerere, J., 1968, Ujamaa: Essays on socialism, Oxford University Press, London.

Odhiambo, N.M., 2009, 'Finance-growth-poverty nexus in South Africa: A dynamic causality linkage', The Journal of Socio-Economics 38, 320-325. http://dx.doi. org/10.1016/j.socec.2008.12.006

Osabu-We, D.T., 2000, Compatible cultural democracy: The key to development in Africa, New York.

Philpott, G. \& Butler, M., 2005, 'Land in South Africa: Gift for all or commodity for a few', Occasional Paper 1, 1-21.

Scheepers, C.L., 2010, 'Ethnicity, cultural diversity and poverty in South Africa: Archaeological perspectives from Iron Age Palestine', Old Testament Essays 23(1) 161-177.

Simutanyi, N., 2010, 'Experiences of nationalisation from selected Southern African countries: Lessons for South Africa, nationalisation in Zambia', in Southern Africa Resource Watch (ed.), Nationalising the mines in South Africa: Prospects, challenges and lessons from the SADC region, pp. 27-33, Southern Africa Resource Watch, Johannesburg.
Shivambu, F., 2014, The coming revolution: Julius Malema and the fight for economic freedom, Jacana Media, Sunnyside.

Shivji, I., 1974, The silent class struggle, Tanzania Publishing House, Dar es Salaam.

Smit, D., 2009, 'Covenanting for justice? On the Accra document, Reformed theology and reformed ecclesiology', HTS Teologiese Studies/Theological Studies 65(1), 589-603. http://dx.doi.org/10.4102/hts.v65i1.279

South African Congress Alliance, 1955, 'The Freedom Charter', Read and adopted in the Congress of the People, Kliptown, viewed 28 May 2013, from http://www.anc. org.za/show.php?id=72

Statistics South Africa (Stats SA), 2012a, GHS Series, vol. IV, Food security and agriculture, 2002-2011: In-depth analysis of the general household survey data, agriculture, $2002-2011:$ In-dept
Statistics South Africa, Pretoria.

Statistics South Africa (Stats SA), 2012b, Social profile of vulnerable groups in South Africa 2002-2011, Statistics South Africa, Pretoria.

Sugirtharajah, R.S., 1999, 'Thinking about vernacular hermeneutics sitting in a metropolitan study', in R.S. Sugirtharajah (ed.), Vernacular hermeneutics, pp. 92-115, Sheffield Academic Press, Sheffield.

Terreblanche, S., 1991, The need for a transformation period towards a post-apartheid South Africa, Stellenbosch Economic Project, Stellenbosch. (Occasional Paper, 3).

Terreblanche, S., 2005, A history of inequality in South Africa, 1652-2002, University of Natal Press, Pietermaritzburg.

Terreblanche, S., 2012, Lost in transformation: South Africa's search for a new future since 1986, KMM Review Publishing Company, Johannesburg.

Truu, M., 1992, 'Nationalisation and privatisation', in R. Schrire (ed.), Wealth or poverty: Critical choices for South Africa, pp. 274-293, Oxford University Press, Cape Town.

Tshaka, R.S., 2010, 'The continued relevance of black liberation theology for democratic South Africa today', Scriptura 105, 532-546. http://dx.doi. org/10.7833/105-0-155

Tshaka, R.S., 2014, 'On being African and reformed? Towards an African reformed theology enthused by an interlocution of those on the margins of society', HTS theology enthused by an interlocution of those on the margins of society', HTS
Teologiese Studies/Theological Studies 70(1), 1-7. http://dx.doi.org/10.4102/hts. v70i1.2070

Van der Westhuizen, C., 2009, 'Power and insecurity: The politics of globalisation', HTS Theological Studies 65(1), 617-623. http://dx.doi.org/10.4102/hts.v65i1.283

West, G., 2010, 'The legacy of liberation theologies in South Africa, with an emphasis on biblical hermeneutics', Studia Historiae Ecclesiasticae 36, 157-183. 